\title{
Tarif Pajak, Sunset Clause, Peredaran Bruto, Kemanfaatan NPWP dan Kepatuhan Wajib Pajak
}

\author{
Desak Kade Bunga Ayu Pradnyani ${ }^{1}$ \\ Fakultas Ekonomi dan Bisnis \\ Universitas Udayana, Indonesia
}

\author{
Naniek Noviari ${ }^{2}$ \\ Fakultas Ekonomi dan Bisnis \\ Universitas Udayana, Indonesia
}

\begin{abstract}
Surel : bungaayupr@gmail.com
ABSTRAK

Kepatuhan wajib pajak UMKM masih rendah, khususnya kepatuhan wajib pajak yang terdaftar di KPP Pratama Tabanan pada tahun 2015-2020. Hal ini tercermin melalui jumlah wajib pajak yang menyampaikan SPT tahunan tidak sebanding dengan jumlah wajib pajak yang terdaftar. Tujuan penelitian ini adalah untuk menguji pengaruh tarif pajak, sunset clause, peredaran bruto dan kemanfaatan NPWP terhadap kepatuhan wajib pajak UMKM. Jumlah sampel yang digunakan sebanyak 100 responden wajib pajak orang pribadi dan badan UMKM dengan menggunakan rumus slovin. Metode penentuan sampel menggunakan teknik nonprobably sampling yaitu accidental sampling. Pengumpulan data dilakukan melalui wawancara dan kuesioner. Teknik analisis yang digunakan dalam penelitian ini adalah analisis regresi linear berganda. Hasil penelitian menunjukkan bahwa tarif pajak, sunset clause, peredaran bruto dan kemanfaatan NPWP berpengaruh positif terhadap kepatuhan wajib pajak UMKM.
\end{abstract}

Kata Kunci: Tarif Pajak; Sunset Clause; Peredaran Bruto; Kemanfaatan NPWP; Kepatuhan Wajib Pajak.

\section{Tax Rates, Sunset Clause, Gross Circulation, Benefits of TIN and Taxpayer Compliance}

\begin{abstract}
MSME taxpayer compliance is still low, especially the compliance of taxpayers registered at the Tabanan Pratama Tax Service Office 20152020. This is reflected in the number of taxpayers who submit annual tax returns that are not proportional to the number of registered taxpayers. The purpose of this study was to examine the effect of tax rates, sunset clause, gross circulation, and the benefits of Taxpayer Identification Numbers (TIN) on MSME taxpayer compliance. The number of samples used was 100 using accidental sampling. Data collection was carried out through interviews and questionnaires. The analysis technique used in this research is multiple linear regression analysis. The results showed that the tax rate, sunset clause, gross circulation, and TIN benefits had a positive effect on MSME taxpayer compliance.
\end{abstract}

Keywords: Tax Rates; Sunset Clause; Gross Circulation; TIN Benefits; Taxpayer Compliance.

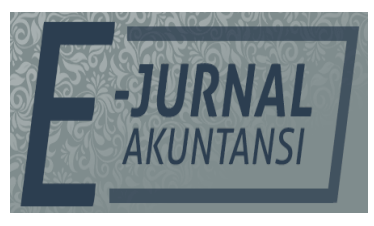

e-ISSN 2302-8556

Vol. 31 No. 10

Denpasar, Oktober 2021

Hal. 2636-2648

DOI:

10.24843/EJA.2021.v31.i10.p18

PENGUTIPAN:

Pradnyani, D.K.B.A., \& Noviari, N. (2021). Tarif Pajak, Sunset Clause,

Peredaran Bruto, Kemanfaatan NPWP dan Kepatuhan Wajib Pajak. EJurnal Akuntansi, 31(10), 2636-2648

RIWAYAT ARTIKEL: Artikel Masuk: 12 April 2021 Artikel Diterima: 12 Mei 2021

Artikel dapat diakses : https://ojs.unud.ac.id/index.php/Akuntansi/index 


\section{PENDAHULUAN}

Penerimaan pajak merupakan hal yang sangat penting dalam kemandirian suatu negara. Hal ini dikarenakan kemandirian suatu negara dapat dilihat apabila negara tersebut mampu membiayai pembangunannya sendiri (Matarirano et al., 2019). Penerimaan negara dari sektor pajak merupakan salah satu bentuk partisipasi masyarakat dalam mewujudkan pembangunan negara (Nkundabanyanga et al., 2017). Pemerintah dalam hal ini Direktorat Jenderal Pajak telah melakukan berbagai upaya untuk memaksimalkan penerimaan pajak. Salah satu upaya yang dilakukan pemerintah adalah pajak penghasilan final yang dikenakan pada UMKM.

Pada tahun 2016 tingkat kepatuhan wajib pajak UMKM mengalami peningkatan dari tahun 2015 yang pada awalnya 24,87 persen menjadi 29,89 persen. Pada tahun 2017 kembali mengalami peningkatan menjadi 35,02 persen. Pada tahun 2018 mengalami sedikit peningkatan yaitu berada pada presentase 37,02 persen. Pada tahun 2019, kembali terjadi kenaikan hingga mencapai kisaran 49,68 persen. Pada tahun 2020 terjadi peningkatan yang cukup pesat yaitu pada kisaran 87,68 persen. Namun capaian kepatuhan pajak tersebut masih belum maksimal karena belum mencapai 100 persen. Hal ini mengindikasikan bahwa kesadaran wajib pajak UMKM di Kabupaten Tabanan belum maksimal.

Besarnya kontribusi UMKM dalam perpajakan menjadi salah satu perhatian bagi pemerintah. Salah satu bentuk perhatian pemerintah dengan diberlakukannya tarif pajak 0,5 persen. Tujuan diberlakukannya PP No. 23 Tahun 2018 diharapkan beban pajak yang ditanggung oleh pelaku UMKM menjadi lebih kecil. Sehingga UMKM memiliki kemampuan ekonomi yang lebih besar untuk mengembangkan usaha dan melakukan investasi (Fauziati \& Kassim, 2018). Penurunan tarif pajak juga bertujuan untuk memberikan motivasi kepada wajib pajak agar mematuhi kewajiban perpajakan dan memberikan keadilan bagi wajib pajak (Gherghina et al., 2020). Pemberlakuan tarif pajak yang adil dapat memengaruhi kepatuhan wajib pajak (Abdul \& Mcfie, 2020).

Faktor lain yang memengaruhi kepatuhan wajib pajak yaitu kebijakan sunset clause. Sunset clause / jangka waktu tertentu yang diberikan oleh pemerintah atas pengenaan tarif pajak final bagi wajib pajak. Sunset clause bertujuan agar wajib pajak UMKM dapat menyelenggarakan pembukuan secara bertahap dan terciptanya ekonomi yang mandiri (Permatasari \& Purposari, 2018). Sunset clause memberikan waktu bagi pelaku UMKM untuk mempersiapkan diri sebelum wajib pajak tersebut melaksanakan hak dan kewajiban pajak secara umum sesuai dengan ketentuan UU Pajak Penghasilan.

Peredaran bruto usaha merupakan salah satu faktor yang memengaruhi kepatuhan wajib pajak. Wajib pajak yang patuh akan melaporkan jumlah peredaran bruto usaha sesuai dengan penghasilan yang diterima. Peredaran bruto dianggap memengaruhi kepatuhan wajib pajak karena wajib pajak cenderung menyembunyikan penghasilannya. Hal ini karena semakin tinggi peredaran bruto maka semakin tinggi pula pajak terutang. Salah satu kewajiban wajib pajak adalah mendaftarkan diri untuk memeroleh nomor pokok wajib pajak (Night \& Bananuka, 2020). Kepemilikan NPWP merupakan suatu kewajiban bagi setiap wajib pajak apabila telah memenuhi persyaratan subjektif dan objektif 
berdasarkan ketentuan peraturan perundang-undangan perpajakan (Paramaduhita \& Mustikasari, 2018).

Kepemilikan NPWP juga dilatarbelakangi oleh berbagai manfaat yang diperoleh wajib pajak atas NPWP tersebut. Wajib pajak akan patuh untuk mendaftarkan diri apabila memeroleh manfaat atas kepemilikan NPWP (Sania \& Yudianto, 2018). Manfaat yang diperoleh wajib pajak atas kepemilikan NPWP dapat memotivasi wajib pajak tidak hanya untuk patuh memiliki NPWP tetapi juga untuk patuh memenuhi kewajiban perpajakan. Teori yang digunakan dalam penelitian ini yaitu Theory of Planned Behavior. Teori ini mengemukakan bahwa perilaku dilakukan karena individu memiliki niat atau keinginan untuk melakukannya (Tucker et al., 2020). Teori ini dapat digunakan untuk menjelaskan keputusan seseorang dalam menentukan perilaku apakah bersedia untuk patuh atau tidak patuh dalam memenuhi kewajiban perpajakannya. Kemauan untuk patuh ini dipengaruhi oleh sikap atau cara pandang individu dan pengaruh orang lain (Nguyen et al., 2019).

Penelitian ini merupakan replika dari penelitian Permatasari \& Purposari (2018), Yuliyanah et al., (2018), dan Dira (2019). Persamaan penelitian ini dengan penelitian sebelumnya terletak pada variabel terikat yang diteliti yaitu variabel kepatuhan wajib pajak. Perbedaan penelitian ini dengan penelitian sebelumnya yaitu terletak pada variabel bebas, objek dan lokasi penelitian. Penelitian sebelumnya menggunakan wajib pajak pribadi UMKM sebagai objek penelitian sedangkan pada penelitian ini yang menjadi objek penelitian adalah wajib pajak pribadi dan badan UMKM. Lokasi penelitian ini terletak di KPP Pratama Tabanan.

Kerangka konseptual dalam penelitian ini merupakan hasil dari penjabaran teori-teori yang sudah ada serta kajian pustaka yang digunakan sebagai tuntutan dalam memecahkan masalah penelitian ini. Kerangka konseptual dari penelitian ini dapat dilihat pada Gambar 1, sebagai berikut.

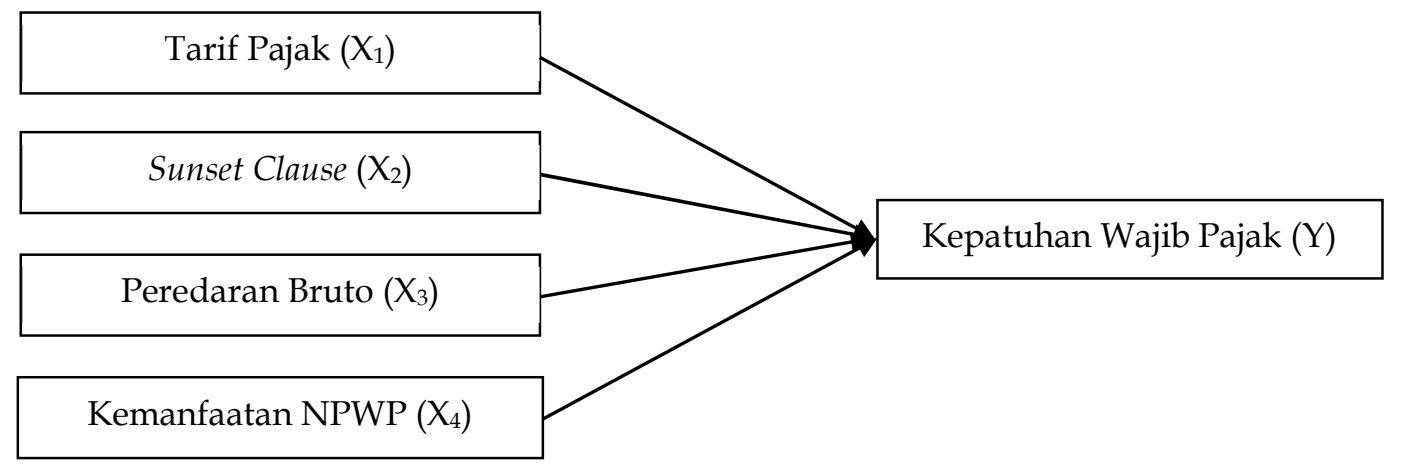

Sumber: Data Penelitian, 2021

\section{Gambar 1. Kerangka Konseptual}

Berdasarkan theory of planned behavior, besarnya tarif pajak berkaitan dengan subjective norm yaitu persepsi individu terhadap harapan dari orang-orang yang berpengaruh dalam kehidupannya mengenai dilakukan atau tidak dilakukannya perilaku tertentu (Munir et al., 2019). Pada hubungan yang bersifat vertikal, harapan dapat dipersepsi sebagai tuntutan sehingga pembentukan norma subjektif akan diwarnai oleh adanya motivasi untuk patuh terhadap tuntutan untuk melakukan atau tidak melakukan sesuatu (Buhmann \& Bronn, 2018). 
Pemerintah menuntut wajib pajak untuk taat akan kewajiban perpajakan. Pemerintah memberikan kebijakan tarif final 0,5 persen bertujuan untuk memberikan motivasi wajib pajak UMKM untuk mematuhi kewajiban perpajakan dan memberikan keadilan bagi wajib pajak UMKM. Alasfour et al., (2016) menyatakan bahwa ketika sistem perpajakan dianggap tidak adil karena tarif pajak terlalu tinggi sehingga wajib pajak mengalami kendala keuangan. Tarif pajak yang adil dan tidak memberatkan bagi wajib pajak UMKM dapat mendorongnya untuk mematuhi kewajiban perpajakan. Semakin adil tarif pajak yang pemerintah tetapkan, maka semakin tinggi kepatuhan wajib pajak untuk melaporkan pajak terutangnya.

Berdasarkan penelitian Meikhati \& Kasetyaningsih (2019) menemukan bahwa penerapan tarif pajak 0,5 persen berpengaruh terhadap kepatuhan wajib pajak untuk membayar pajak. Pernyataan tersebut didukung oleh penelitian Noviana et al., (2019) menemukan bahwa penerapan PP Nomor 23 Tahun 2018 berpengaruh secara positif dan signifikan terhadap kepatuhan wajib pajak UMKM. Berdasarkan penelitian terdahulu yang dilakukan oleh Nadhor et al., (2020) menyatakan bahwa penurunan tarif pajak UMKM berpengaruh positif terhadap persepsi wajib pajak mengenai kepatuhan pajak. Kumaratih \& Ispriyarso (2020) menemukan bahwa kebijakan penurunan tarif PPh Final 0,5 persen merupakan faktor pendukung meningkatnya kepatuhan pelaku usaha UMKM sebagai wajib pajak. Indriana et al., (2020) menemukan bahwa penerapan PP No. 23 Tahun 2018 berpengaruh positif terhadap kepatuhan wajib pajak. Berdasarkan uji empiris sebelumnya, hipotesis yang dapat diajukan dalam penelitian ini adalah sebagai berikut.

$\mathrm{H}_{1}$ : Tarif pajak berpengaruh positif terhadap kepatuhan wajib pajak.

Berdasarkan Theory of Planned Behavior, sunset clause berkaitan dengan perceived behavioral control yaitu persepsi individu mengenai mudah atau sulitnya mewujudkan suatu perilaku tertentu. Persepsi kontrol perilaku ditentukan oleh keyakinan individu mengenai ketersediaan sumberdaya berupa peralatan, kompatibelitas, kompetensi, dan kesempatan (control belief strength) yang mendukung atau menghambat perilaku yang akan diprediksi dan besarnya peran sumber daya tersebut dalam mewujudkan perilaku.

Sunset clause merupakan suatu kebijakan yang diberikan pemerintah kepada wajib pajak UMKM berupa jangka waktu atas pengenaan tarif pajak final. Sunset clause atau jangka waktu pengenaan ini dimaksudkan agar wajib pajak dapat menyelenggarakan pembukuan secara bertahap dan mengembangkan usaha. Sehingga sunset clause menjadi suatu kesempatan untuk belajar secara bertahap bagi wajib pajak yang awalnya merasa kesulitan untuk memenuhi kewajiban perpajakan karena kurangnya pemahaman dalam pembukuan dan penyusunan laporan keuangan sesuai dengan standar akuntansi. Pemberlakuan sunset clause (jangka waktu) membuat masyarakat tidak terlalu keberatan untuk memenuhi kewajiban pajaknya. Hal ini karena jangka waktu yang diberikan mendorong wajib pajak dalam menyelenggarakan dan pengembangan usaha. Sehingga semakin cukup waktu bagi pelaku UMKM dalam menyelenggarakan dan pengembangan usaha maka semakin tinggi tingkat kepatuhan wajib pajak. Permatasari \& Purposari (2018) menemukan bahwa sunset clause berpengaruh positif terhadap kepatuhan wajib pajak 
$\mathrm{H}_{2}$ : Sunset clause berpengaruh positif terhadap kepatuhan wajib pajak.

Wajib pajak merasa keberatan untuk membayar pajak apabila dikenakan pajak atas penghasilan yang tidak seberapa (rendah) dari yang mereka terima, sehingga cenderung untuk menolak atau tidak patuh untuk membayar pajak. Sebaliknya wajib pajak merasa bahwa mereka akan lebih mudah atau lebih sadar untuk membayar pajak ketika peredaran bruto mereka tinggi atau ketika memang omzet mereka sudah mencapai kriteria yang harus dikenakan pajak oleh pemerintah. Hal ini dikarenakan wajib pajak merasa mampu untuk membayar pajak ketika peredaran bruto usaha mereka tinggi. Sehingga semakin tinggi peredaran bruto maka semakin tinggi pula kepatuhan wajib pajak.

Berdasarkan penelitian Supriyono et al., (2021) terdahulu menemukan bahwa peredaran bruto berpengaruh secara signifikan terhadap kepatuhan wajib pajak. Hasil penelitian ini mendukung penelitian terdahulu yang dilakukan oleh Hanifah \& Yudianto (2019) menemukan bahwa peredaran bruto berpengaruh secara positif dan signifikan terhadap kepatuhan wajib pajak usahawan. Yuliyanah et al. (2018) menemukan bahwa peredaran bruto berpengaruh positif terhadap kepatuhan wajib pajak UMKM. Penelitian ini sejalan dengan penelitian yang dilakukan oleh Manafe et al., (2020) menemukan bahwa peredaran bruto berpengaruh signifikan terhadap kepatuhan wajib pajak.

$\mathrm{H}_{3}$ : Peredaran bruto berpengaruh positif terhadap kepatuhan wajib pajak.

Wajib pajak akan patuh untuk mendaftarkan diri apabila memeroleh manfaat atas kepemilikan NPWP (Sania \& Yudianto, 2018). Manfaat yang diperoleh wajib pajak atas kepemilikan NPWP dapat memotivasi wajib pajak tidak hanya untuk patuh memiliki NPWP tetapi juga untuk patuh memenuhi kewajiban perpajakan. Hasil penelitian ini mendukung penelitian terdahulu dari Dira (2019) menemukan bahwa kemanfaatan NPWP berpengaruh positif dan signifikan terhadap kepatuhan wajib pajak. Taurina et al., (2017) menemukan bahwa kemanfaatan NPWP berpengaruh positif terhadap kepatuhan wajib pajak. Sania \& Yudianto (2018) menemukan bahwa kemanfaatan NPWP secara simultan berpengaruh signifikan terhadap kepatuhan wajib pajak.

$\mathrm{H}_{4}$ : Kemanfaatan NPWP berpengaruh positif terhadap kepatuhan wajib pajak.

\section{METODE PENELITIAN}

Desain penelitian yang digunakan dalam penelitian ini adalah pendekatan kuantitatif berbentuk asosiatif. Pendekatan kuantitatif yang berbentuk asosiatif menjelaskan pengaruh variabel independen pada variabel dependen yakni untuk mengetahui pengaruh tarif pajak, sunset clause, peredaran bruto dan kemanfaatan NPWP terhadap kepatuhan wajib pajak UMKM. Penelitian ini dilakukan di KPP Pratama Tabanan karena jumlah pelaku UMKM di Kabupaten Tabanan mengalami peningkatan di setiap tahunnya namun tidak sebanding dengan jumlah wajib pajak UMKM yang mendaftarkan diri di KPP Pratama Tabanan. Disamping itu kepatuhan wajib pajak UMKM di Kabupaten Tabanan belum maksimal jika dilihat dari jumlah wajib pajak yang menyampaikan SPT tahunnya. Hal ini mengindikasikan bahwa adanya ketidakpatuhan pelaku UMKM dalam memenuhi kewajiban perpajakan. Objek dari penelitian ini terdiri dari kepatuhan wajib pajak UMKM, tarif pajak, sunset clause, peredaran bruto dan kemanfaatan NPWP. 
Data kuantitatif dalam penelitian ini adalah data jumlah UMKM di Kabupaten Tabanan, jumlah wajib pajak UMKM terdaftar dan data jumlah wajib pajak UMKM yang menyampaikan SPT di KPP Pratama Tabanan serta hasil kuesioner yang sudah dikuantitatifkan. Penelitian ini menggunakan data kualitatif berupa nama, skema struktur organisasi serta gambaran umum KPP Pratama Tabanan. Data primer yang digunakan dalam penelitian ini diperoleh melalui pernyataan responden dalam menjawab kuesioner yang disebarkan pada KPP Pratama Tabanan. Data sekunder yang digunakan dalam penelitian ini berupa data jumlah UMKM di Kabupaten Tabanan yang diperoleh dari Dinas Koperasi dan UMKM Kabupaten Tabanan, data jumlah wajib pajak UMKM yang terdaftar dan data jumlah wajib pajak UMKM yang menyampaikan SPT tahunan di KPP Pratama Tabanan dari tahun 2015-2020. Penelitian ini menggunakan kuesioner sebagai metode pengumpulan data primer, maka perlu dilakukan uji validitas dan reliabilitas agar kuesioner layak digunakan. Pengukuran atas jawaban dari tanggapan responden menggunakan skala likert. Skala ini digunakan untuk sikap, pendapat, dan persepsi orang atau kelompok orang tentang fenomena sosial. Pernyataan ini akan diukur dengan skala 1 sampai 5 .

Populasi dalam penelitian ini adalah seluruh wajib pajak UMKM yang terdaftar di KPP Pratama Tabanan pada tahun 2020 yang berjumlah 105.103 wajib pajak. Sampel dalam penelitian ini adalah wajib pajak UMKM yang terdaftar di KPP Pratama Tabanan pada tahun 2020 berjumlah 100 responden. Teknik sampel yang digunakan dalam penelitian ini menggunakan metode accidental sampling. Kriteria yang dipilih sebagai responden yaitu wajib pajak UMKM (memiliki peredaran bruto tidak melebihi 4,8 miliar dalam satu tahun) yang terdaftar di KPP Pratama Tabanan. Teknik pengumpulan data dalam penelitian ini adalah Wawancara dan Kuesioner Teknik analisis data yang digunakan dalam penelitian ini yaitu analisis regresi linier berganda. Analisis data dilakukan dengan menggunakan program Statistical Package for Social Science (SPSS). Persamaan matematis untuk hubungan yang dihopetesiskan dapat dirumuskan sebagai berikut.

$Y=\alpha+\beta_{1} X_{1}+\beta_{2} X_{2}+\beta_{3} X_{3}+\beta_{4} X_{4}+\beta_{5} X_{5}+\varepsilon$

\section{HASIL DAN PEMBAHASAN}

Penggambaran mengenai responden dalam penelitian ini akan dijelaskan dengan menyajikan karakteristik responden yang didasarkan pada 4 aspek, yaitu jenis kelamin, jenis usaha, kepemilikan NPWP, peredaran bruto dan skala usaha. Berdasarkan jenis kelamin, jumlah responden yang mendominasi yaitu berjenis kelamin laki-laki dengan presentase 73 persen dan responden berjenis kelamin perempuan dengan presentase 27 persen. Maka dapat disimpulkan bahwa sebagian besar wajib pajak UMKM yang terdaftar di KPP Pratama Tabanan adalah berjenis kelamin laki-laki. Berdasarkan jenis usaha, mayoritas jenis usaha yang digeluti responden adalah perdagangan dengan presentase 75 persen, jasa tidak sehubungan pekerjaan bebas dengan presentase 19 persen, jasa sehubungan pekerjaan bebas dengan presentase 0 persen dan jenis usaha industri dengan presentase 6 persen.

Berdasarkan kepemilikan NPWP, jumlah responden yang memiliki NPWP sejumlah 100 orang dan responden yang tidak memiliki NPWP sejumlah 0 orang. 
Berdasarkan peredaran bruto, dapat disimpulkan bahwa mayoritas responden memiliki peredaran bruto $\leq 4,8$ miliar yaitu sejumlah 100 orang. Hal tersebut sejalan dengan kriteria responden yang digunakan dalam penelitian ini yaitu Wajib Pajak UMKM yang memiliki peredaran bruto $\leq 4,8$ miliar dalam setahun. Mayoritas responden memiliki jenis usaha mikro (memiliki omset tahunan maksimal Rp 300.000.000,00) yakni sejumlah 56 UMKM (56 persen) dengan ratarata peredaran bruto sebesar Rp. 115.273.971,23. Selanjutnya 39 UMKM (39 persen) merupakan jenis usaha kecil (memiliki omset tahunan antara Rp 300.000.000,00 hingga $\mathrm{Rp} 2.500 .000 .000,00)$ dengan rata-rata peredaran bruto sebesar Rp.725.145.180,61. Kemudian sisanya 5 UMKM (5 persen) merupakan usaha menengah (memiliki omset tahunan antara Rp 2.500.000.000,00 hingga $\mathrm{Rp}$ 50.000.000.000,00) dengan rata-rata peredaran bruto sebesar Rp. 3.304.076.000,00. Berdasarkan jenis kepemilikan, mayoritas responden berasal dari wajib pajak pribadi UMKM yaitu sejumlah 79 wajib pajak dan 21 lainnya merupakan wajib pajak badan UMKM.

Hasil uji validitas menunjukkan bahwa seluruh instrumen penelitian yang digunakan untuk mengukur variabel tarif pajak, sunset clause, peredaran bruto, kemanfaatan NPWP, dan kepatuhan wajib pajak memiliki nilai koefisien korelasi dengan skor total seluruh item pernyataan lebih besar dari 0,30 dengan signifikansi kurang dari 0,05. Hal ini menunjukkan bahwa butir-butir pernyataan dalam instrument penelitian tersebut valid dan layak digunakan sebagai instrument penelitian. Hasil uji reliabilitas menunjukkan bahwa seluruh instrumen penelitian memiliki koefisien Cronbach's Alpha lebih dari 0,60. Sehingga dapat dinyatakan bahwa seluruh variabel telah memenuhi syarat reliabilitas atau kehandalan sehingga dapat digunakan untuk melakukan penelitian.

Tabel 1. Hasil Uji Statistik Deskriptif

\begin{tabular}{llllll}
\hline Variabel & $\mathrm{N}$ & Minimum & Maximum & Mean & $\begin{array}{l}\text { Std. } \\
\text { Deviation }\end{array}$ \\
\hline Tarif Pajak $\left(\mathrm{X}_{1}\right)$ & 100 & 32 & 63 & 51,66 & 6,503 \\
Sunset Clause $\left(\mathrm{X}_{2}\right)$ & 100 & 9 & 20 & 15,91 & 2,621 \\
Peredaran Bruto $\left(\mathrm{X}_{3}\right)$ & 100 & 12 & 25 & 20,72 & 3,078 \\
Kemanfaatan Npwp $\left(\mathrm{X}_{4}\right)$ & 100 & 29 & 40 & 34,61 & 3,484 \\
Kepatuhan Wajib Pajak $(\mathrm{Y})$ & 100 & 23 & 40 & 33,52 & 3,955 \\
\hline
\end{tabular}

Sumber: Data Penelitian, 2021
Variabel Tarif Pajak $\left(X_{1}\right)$ memiliki nilai minimum sebesar 32, nilai maksimum sebesar 63, mean sebesar 51,66 dan standar deviasi sebesar 6,503. Hal ini menunjukkan bahwa standar penyimpangan data terhadap nilai rata-ratanya adalah 6,503. Variabel Sunset Clause $\left(X_{2}\right)$ memiliki nilai minimum sebesar 9, nilai maksimum sebesar 20, mean sebesar 15,91 dan standar deviasi sebesar 2,621. Hal ini menunjukkan bahwa standar penyimpangan data terhadap nilai rata-ratanya adalah 2,621. Variabel Peredaran Bruto $\left(X_{3}\right)$ memiliki nilai minimum sebesar 12, nilai maksimum sebesar 25, mean sebesar 20,71 dan standar deviasi sebesar 3,078. Hal ini menunjukkan bahwa standar penyimpangan data terhadap nilai rataratanya adalah 3,078. Variabel Kemanfaatan NPWP $\left(X_{4}\right)$ memiliki nilai minimum sebesar 29, nilai maksimum sebesar 40, mean sebesar 34,61 dan standar deviasi sebesar 3,484. Hal ini menunjukkan bahwa standar penyimpangan data terhadap 
nilai rata-ratanya adalah 3,484 Variabel Kepatuhan Wajib Pajak (Y) memiliki nilai minimum sebesar 23, nilai maksimum sebesar 40, mean sebesar 33,52 dan standar deviasi sebesar 3,955. Hal ini menunjukkan bahwa standar penyimpangan data terhadap nilai rata-ratanya adalah 3,955.

Tabel 2. Hasil Uji Normalitas

\begin{tabular}{lll}
\hline No. & Kolmogorov-Smirnov Z & Unstandardized Residual \\
\hline 1. & $\mathrm{~N}$ & 100 \\
2. & Kolmogorov-Smirnov Z & 0,701 \\
3. & Asymp. Sig. (2-tailed) & 0,710
\end{tabular}

Sumber: Data Penelitian, 2021

Berdasarkan hasil analisis pada Tabel 2, didapat nilai signifikansi sebesar 0,710. Karena nilai signifikansi uji Kolmogorov-Smirnov lebih dari 0,05 maka dapat disimpulkan bahwa model persamaan regresi tersebut berdistribusi normal.

Tabel 3. Hasil Uji Multikoleniaritas

\begin{tabular}{llll}
\hline No. & Variabel & Tolerance & VIF \\
\hline 1. & Tarif Pajak $\left(\mathrm{X}_{1}\right)$ & 0,746 & 1,341 \\
2. & Sunset Clause $\left(\mathrm{X}_{2}\right)$ & 0,712 & 1,404 \\
3. & Peredaran Bruto $\left(\mathrm{X}_{3}\right)$ & 0,696 & 1,438 \\
4. & Kemanfaatan NPWP $\left(\mathrm{X}_{4}\right)$ & 0,771 & 1,297
\end{tabular}

Sumber: Data Penelitian, 2021

Berdasarkan Tabel 3, dapat dilihat bahwa nilai tolerance dan VIF dari seluruh variable tersebut menunjukkan bahwa nilai tolerance untuk setiap variabel lebih besar dari 10 persen dan nilai VIF lebih kecil dari 10 yang berarti model persamaan regresi bebas dari multikolinearitas.

Tabel 4. Hasil Uji Heterokedasitas

\begin{tabular}{lll}
\hline No. & Variabel Bebas & Signifikansi \\
\hline 1. & Tarif pajak & 0,682 \\
2. & Sunset clause & 0,669 \\
3. & Peredaran bruto & 0,253 \\
4. & Kemanfaatan NPWP & 0,380 \\
\hline
\end{tabular}

Sumber: Data Penelitian, 2021

Pada Tabel 4, dapat dilihat bahwa nilai Signifikansi dari variabel tarif pajak sebesar 0,682, sunset clause sebesar 0,669, peredaran bruto sebesar 0,253, dan kemanfaatan NPWP sebesar 0,380. Nilai tersebut lebih besar dari 0,05 yang berarti tidak terdapat pengaruh antara variabel bebas terhadap absolute residual. Dengan demikian, model yang dibuat tidak mengandung gejala heteroskedastisitas.

Besarnya pengaruh variabel bebas terhadap variabel terikat yang ditunjukkan oleh nilai determinasi total ( $R$ Square) sebesar 0,687 mempunyai arti bahwa sebesar 68,7 persen variasi kepatuhan wajib pajak dipengaruhi oleh variasi tarif pajak, sunset clause, peredaran bruto, dan kemanfaatan NPWP, sedangkan sisanya sebesar 31,3 persen djelaskan oleh faktor lain yang tidak dimasukkan ke dalam model. nilai $F_{\text {hitung }}$ sebesar 52,127 dengan nilai sig. 0,000 0,05, maka disimpulkan bahwa pada kelompok yang diuji memiliki perbedaan yang nyata (signifikan). Hasil ini mempunyai arti bahwa ada pengaruh signifikan antara 
faktor tarif pajak, sunset clause, peredaran bruto, dan kemanfaatan NPWP secara simultan terhadap kepatuhan wajib pajak

Tabel 5. Hasil Analisis Regresi Linier Berganda

\begin{tabular}{|c|c|c|c|c|c|c|}
\hline No. & Variabel & $\begin{array}{l}\text { Unstandardized } \\
\text { Beta }\end{array}$ & $\begin{array}{l}\text { Std. } \\
\text { Error }\end{array}$ & $\begin{array}{l}\text { Standardized } \\
\text { Beta }\end{array}$ & T hitung & Sig. Uji t \\
\hline 1. & Constant & $-2,164$ & 2,575 & & $-0,840$ & 0,403 \\
\hline 2. & Tarif Pajak $\left(X_{1}\right)$ & 0,084 & 0,040 & 0,139 & 2,088 & 0,039 \\
\hline 3. & $\begin{array}{l}\text { Sunset Clause } \\
\left(\mathrm{X}_{2}\right)\end{array}$ & 0,265 & 0,103 & 0,176 & 2,583 & 0,011 \\
\hline 4. & $\begin{array}{l}\text { Peredaran } \\
\text { Bruto }\left(X_{3}\right)\end{array}$ & 0,295 & 0,088 & 0,230 & 3,340 & 0,001 \\
\hline 5. & $\begin{array}{l}\text { Kemanfaatan } \\
\text { NPWP }\left(X_{4}\right)\end{array}$ & 0,606 & 0,074 & 0,534 & 8,171 & 0,000 \\
\hline $\begin{array}{l}\text { Adju } \\
\mathrm{F}: 52\end{array}$ & $\begin{array}{l}\text { ed R Square: } 0,674 \\
27\end{array}$ & & & & & \\
\hline
\end{tabular}

Sumber: Data Penelitian, 2021

Tarif pajak menghasilkan nilai signifikansi yaitu 0,039 dengan nilai $t_{\text {hitung }}$ sebesar 2,088. Signifikansi $X_{1}$ yaitu 0,039 yaitu lebih rendah dengan 0,05 $(0,0039<$ $0,05)$. Hal ini menunjukkan bahwa hasil pengujian sejalan dengan hipotesis alternatif pertama $\left(\mathrm{H}_{1}\right)$ yang menyatakan tarif pajak berpengaruh positif terhadap kepatuhan wajib pajak. Jadi semakin adil tarif pajak yang diberikan, maka kepatuhan WP UMKM semakin meningkat. Hal ini ini berarti ketika tarif pajak semakin kecil maka kesadaran wajib pajak UMKM untuk melakukan pemenuhan perpajakan semakin meningkat. Karena persepsi wajib pajak mengenai tarif pajak yang semakin rendah maka pajak yang dibayarkan akan semakin kecil. Sehingga hal tersebut akan mengurangi pengeluaran untuk membayar pajak dimana akan menguntungkan usahanya. Hasil ini mendukung Theory of Planned Behavior bahwa tarif pajak berkaitan dengan subjective norm. Penelitian ini sejalan dengan penelitian dari Noviana et al., (2019), Nadhor et al., (2020), Indriana et al., (2020) yang menyatakan bahwa tarif pajak berpengaruh positif terhadap kepatuhan wajib pajak.

Sunset clause menghasilkan nilai signifikansi yaitu 0,011 dengan nilai $t_{\text {hitung }}$ sebesar 2,583. Signifikansi $X_{2}$ yaitu 0,011 yaitu lebih rendah dengan 0,05 (0,0011 < $0,05)$. Hal ini menunjukkan bahwa hasil pengujian sejalan dengan hipotesis alternatif kedua $\left(\mathrm{H}_{2}\right)$ yang menyatakan sunset clause berpengaruh positif terhadap kepatuhan wajib pajak. Jadi semakin adil sunset clause maka tingkat kepatuhan WP UMKM semakin tinggi. Hal ini berarti bahwa sunset clause memberikan kesempatan bagi WP UMKM untuk belajar secara bertahap dalam menyelenggarakan pembukuan dan mengembangkan usaha. Sunset clause menjadi suatu kesempatan untuk belajar secara bertahap bagi wajib pajak yang awalnya merasa kesulitan untuk memenuhi kewajiban perpajakan karena kurangnya pemahaman dalam pembukuan dan penyusunan laporan keuangan sesuai dengan standar akuntansi. Pemberlakuan sunset clause (jangka waktu) mendorong wajib pajak untuk patuh dan tidak terlalu keberatan untuk memenuhi kewajiban pajaknya. Hasil ini mendukung theory of planned behavior bahwa sunset clause berkaitan dengan perceived behavioral control. Penelitian ini sejalan dengan 
penelitian dari Permatasari \& Purposari (2018) yang menyatakan bahwa sunset clause berpengaruh positif terhadap kepatuhan wajib pajak.

Peredaran bruto menghasilkan nilai signifikansi yaitu 0,001 dengan nilai $t_{\text {hitung }}$ sebesar 3,340. Signifikansi $X_{3}$ yaitu 0,001 yaitu lebih rendah dengan 0,05 $(0,001<0,05)$. Hal ini menunjukkan bahwa hasil pengujian sejalan dengan hipotesis alternatif ketiga $\left(\mathrm{H}_{3}\right)$ yang menyatakan peredaran bruto berpengaruh positif terhadap kepatuhan wajib pajak. Jadi semakin tinggi nilai peredaran bruto maka kepatuhan wajib pajak UMKM semakin tinggi. Hal ini berarti bahwa wajib pajak akan lebih patuh untuk membayar pajak ketika nilai peredaran bruto tinggi. Kebanyakan wajib pajak merasa keberatan untuk membayar pajak ketika nilai peredaran bruto usaha mereka rendah, khususnya wajib pajak UMKM yang masih dalam kategori mikro. Hasil ini mendukung Theory of Planned Behavior bahwa peredaran bruto berkaitan dengan attitude toward the behavior. Penelitian ini sejalan dengan penelitian dari Manafe et al., (2020) yang menyatakan bahwa peredaran bruto berpengaruh positif terhadap kepatuhan wajib pajak.

Kemanfaatan NPWP menghasilkan nilai signifikansi yaitu 0,000 dengan nilai $t_{\text {hitung }}$ sebesar 8,171 . Signifikansi $X_{3}$ yaitu 0,000 yaitu lebih rendah dengan 0,05 $(0,000<0,05)$. Hal ini menunjukkan bahwa hasil pengujian sejalan dengan hipotesis alternatif keempat $\left(\mathrm{H}_{4}\right)$ yang menyatakan kemanfaatan NPWP berpengaruh positif terhadap kepatuhan wajib pajak. Jadi semakin banyak manfaat yang dirasakan wajib pajak akan kepemilikan NPWP maka kepatuhan wajib pajak semakin tinggi. Hal ini berarti bahwa manfaat yang diberikan dari kepemilikan NPWP yang selaras dengan kepentingan wajib pajak sehingga WP termotivasi untuk membayar dan melaporkan pajaknya daripada wajib pajak yang tidak memiliki NPWP. Hasil ini mendukung Theory of Planned Behavior bahwa peredaran bruto berkaitan dengan attitude toward the behavior. Penelitian ini sejalan dengan penelitian dari Taurina et al., (2017) yang menyatakan bahwa kemanfaatan NPWP berpengaruh positif terhadap kepatuhan wajib pajak.

Penelitian ini menghasilkan simpulan mengenai pengaruh tarif pajak, sunset clause, peredaran bruto dan kemanfaatan NPWP terhadap kepatuhan wajib pajak UMKM di KPP Pratama Tabanan. Hasil uji dalam penelitian ini menemukan bahwa variabel independen yaitu tarif pajak, sunset clause, peredaran bruto dan kemanfaatan NPWP berpengaruh positif terhadap kepatuhan wajib pajak UMKM. Penelitian ini mendukung Theory of Planed Behavior yaitu menjelaskan keputusan seseorang dalam menentukan perilaku untuk patuh dalam memenuhi kewajiban perpajakannya. Kemauan untuk patuh ini dipengaruhi oleh sikap atau cara pandang individu dan pengaruh orang lain. Penelitian ini dapat digunakan sebagai motivasi untuk meningkatkan kesadaran wajib pajak bagi instansi pajak untuk terus meningkatkan kesadaran wajib pajak khususnya pelaku wajib pajak UMKM di Kabupaten Tabanan. Hal ini bertujuan agar mereka menjadi wajib pajak yang aktif serta memahami akan pentingnya membayar pajak. Sehingga tidak terjadi tunggakan atau hutang pajak dari wajib pajak. Bagi peneliti selanjutnya diharapkan penelitian ini dapat menjadi bahan rujukan untuk menambah informasi yang diperlukan dan sebagai acuan dalam penelitian yang dilakukan. 


\section{SIMPULAN}

Penelitian ini menguji pengaruh tarif pajak, sunset clause, peredaran bruto dan kemanfaatan NPWP terhadap kepatuhan wajib pajak UMKM. Lokasi penelitian ini dilakukan di KPP Pratama Tabanan dengan mengambil sampel sebanyak 100 wajib pajak dari 105.103 jumlah populasi keseluruhan. Berdasarkan hasil analisis dan pembahasan hasil penelitian yang telah diuraikan pada bab sebelumnya, maka dapat disimpulkan bahwa tarif pajak berpengaruh positif terhadap kepatuhan wajib pajak UMKM di KPP Pratama Tabanan. Hal ini berarti semakin adil tarif pajak maka semakin tinggi pula tingkat kepatuhan wajib pajak. Sunset clause berpengaruh positif terhadap kepatuhan wajib pajak UMKM di KPP Pratama Tabanan. Hal ini berarti semakin adil sunset clause maka semakin tinggi pula tingkat kepatuhan wajib pajak. Peredaran bruto berpengaruh positif terhadap kepatuhan wajib pajak UMKM di KPP Pratama Tabanan. Hal ini berarti semakin tinggi nilai peredaran bruto maka semakin tinggi pula tingkat kepatuhan wajib pajak. Kemanfaatan NPWP berpengaruh positif terhadap kepatuhan wajib pajak UMKM di KPP Pratama Tabanan. Hal ini berarti semakin banyak manfaat yang dirasakan wajib pajak atas kepemilikan NPWP maka semakin tinggi pula tingkat kepatuhan wajib pajak.

Bagi penelitian selanjutnya yang tertarik melakukan kajian di bidang yang sama hendaknya menambah variabel independen yang berpengaruh terhadap kepatuhan wajib pajak. Selain itu peneliti selanjutnya dapat menggunakan variabel-variabel baru yang tidak digunakan dalam penelitian ini, seperti sosialisasi pajak, pemahaman wajib pajak dan kualitas pelayanan fiskus, dst. Sehingga dapat ditemukan variabel baru yang akan meningkatkan kepatuhan wajib pajak. Berdasarkan hasil penelitian, variabel kemanfaatan NPWP merupakan faktor yang paling berpengaruh terhadap kepatuhan wajib pajak. Disarankan bagi wajib pajak yang memiliki NPWP lebih diberikan kemudahan dalam pengajuan kredit bank untuk pengembangan usahanya serta dipermudah dalam perizinan usaha. Sehingga akan mendorong wajib pajak untuk patuh akan kewajiban perpajakan.

Berdasarkan hasil pengujian disimpulkan bahwa tarif pajak berpengaruh terhadap kepatuhan wajib pajak UMKM. Diharapkan pengenaan tarif pajak tetap meninjau kemampuan UMKM sehingga tidak memberatkan dan wajib pajak akan lebih patuh memenuhi kewajiban perpajakannya. Berdasarkan hasil pengujian disimpulkan bahwa peredaran bruto berpengaruh terhadap kepatuhan wajib pajak UMKM. Diharapkan wajib pajak secara transparan melaporkan pajak berdasarkan nilai peredaran bruto yang mereka terima. Penelitian selanjutnya disarankan dapat menambah jumlah sampel penelitian dan memperluas wilayah sampel sehingga hasil penelitian memberikan gambaran yang riil sesuai dengan yang diharapkan. Penelitian selanjutnya disarankan menggunakan metode wawancara disamping metode kuesioner untuk mengetahui secara benar jawaban dari responden.

\section{REFERENSI}

Abdul, F., \& Mcfie, J. B. (2020). Tax Complexity and Compliance Behaviour of Large and Medium Sized Business Tax Payers in Kenya. Review of Integrative Business and Economics Research, 9(2), 90-106. 
Alasfour, F., Samy, M., \& Bampton, R. (2016). The determinants of tax morale and tax compliance: Evidence from Jordan. In Advances in Taxation, 23(1), 1. https://doi.org/https://doi.org/10.1108/S1058-749720160000023005

Buhmann, A., \& Brønn, P. . (2018). Applying Ajzen's theory of planned behavior to predict practitioners' intentions to measure and evaluate communication outcomes. Corporate Communications: An International Journal, 23(3), 377-391. https://doi.org/https://doi.org/10.1108/CCIJ-11-2017-0107

Dira, P. R. (2019). Pengaruh Pemahaman Akuntansi, Kepemilikan Npwp Dan Pemeriksaan Pajak Terhadap Kepatuhan Wajib Pajak Badan Di Kantor Pelayanan Pajak (Kpp) Madya Pekanbaru. Kutubkhanah, 53(9), 1689-1699.

Fauziati, P., \& Kassim, A. A. M. (2018). The effect of business characteristics on tax compliance costs. Management Science Letters, 8(5), 353-358. https://doi.org/https://doi.org/10.5267/j.msl.2018.4.013

Gherghina, S. C., Botezatu, M. A., Hosszu, A., \& Simionescu, L. N. (2020). Small and medium-sized enterprises (SMEs): The engine of economic growth through investments and innovation. Sustainability (Switzerland), 12(1), 1-21. https:// doi.org/10.3390/SU12010347

Hanifah, H., \& Yudianto, I. (2019). The Influence of Religiosity, Nationalism, and Tax Corruption Perception on Tax Compliance: Study of The Micro, Small and Medium Enterprises (MSMEs) Taxpayers in Bandung City. Journal of $\begin{array}{llll}\text { Accounting Auditing and } 17 . & \end{array}$ https://doi.org/10.24198/jaab.v2i1.20428

Indriana, M., Moh, N., \& Faisol. (2020). Tarif Pajak UMKM 0,5 persen : Reward Or Punishment? InFestasi, 16(1), 88-100. https://doi.org/https://doi.org/10.21107/infestasi.v16i1.6986

Kumaratih, C., \& Ispriyarso, B. (2020). Pengaruh Kebijakan Perubahan Tarif PPH Final Terhadap Kepatuhan Wajib Pajak Pelaku UMKM. Jurnal Diponegoro, 2(23), 158-173.

Manafe, R. S. S., Simanjuntak, A. M. A., \& Andriati, H. N. (2020). Pengaruh Pemahaman Peraturan, Omset, Pemeriksaan, Sanksi, Relasi Sosial, dan Persaingan Usaha Terhadap Kepatuhan Wajib Pajak Restoran. Jurnal Akuntansi \& Keuangan Daerah, 15(1), 77-91.

Matarirano, O., Chiloane-Tsoka, G. E., \& Makina, D. (2019). Tax compliance costs and small business performance: Evidence from the South African construction industry. South African Journal of Business Management, 50(1), 19. https://doi.org/https://doi.org/10.4102/sajbm.v50i1.336

Meikhati, E., \& Kasetyaningsih, S. W. (2019). Pengaruh Penerapan PP 23 Tahun 2018 terhadap Tingkat Kepatuhan Pembayaran Pajak UMKM. Proceeding Seminar Nasional \& Call For Papers, September, ., 1(1), 50-59.

Munir, H., Jianfeng, C., \& Ramzan, S. (2019). Personality traits and theory of planned behavior comparison of entrepreneurial intentions between an emerging economy and a developing country. International Journal of Entrepreneurial Behavior $\mathcal{E}$ Research, 25(3), 554-580. https://doi.org/https://doi.org/10.1108/IJEBR-05-2018-0336

Nadhor, K., Fatoni, N., Nurudin, \& Zakiy, F. S. (2020). Pelayanan Online Terhadap Persepsi Wajib Pajak ( Studi Pada UMKM yang Terdaftar di KPP Semarang Barat ). Paj. Akuntansi, 11(1), 88-113. 
Nguyen, T.-M., Nham, P. T., \& Hoang, V.-N. (2019). The theory of planned behavior and knowledge sharing: A systematic review and meta-analytic structural equation modelling. VINE Journal of Information and Knowledge $\begin{array}{llll}\text { Management } \quad \text { Systems, } & \text { 49(1), }\end{array}$ https://doi.org/https://doi.org/10.1108/VJIKMS-10-2018-0086

Night, S., \& Bananuka, J. (2020). The mediating role of adoption of an electronic tax system in the relationship between attitude towards electronic tax system and tax compliance. Journal of Economics, Finance and Administrative Science, 25(49), 73-88. https://doi.org/https://doi.org/10.1108/JEFAS-07-2018-0066

Nkundabanyanga, S. K., Mvura, P., Nyamuyonjo, D., Opiso, J., \& Nakabuye, Z. (2017). Tax compliance in a developing country: Understanding taxpayers' compliance decision by their perceptions. Journal of Economic Studies, 44(6), 931-957. https:/ / doi.org/https://doi.org/10.1108/JES-03-2016-0061

Noviana, R., Afifudin, \& Hariri. (2019). Pengaruh Sosialisasi Pajak, Tarif Pajak, Penerapan Pp No. 23 Tahun 2018, Dan Sanksi Perpajakan Terhadap Kepatuhan Wajib Pajak UMKM. E-Jra, 8(9), 1-13.

Paramaduhita, A. V., \& Mustikasari, E. (2018). Non-employee individual taxpayer compliance: Relationship with income and perception of taxpayer. Asian Journal of Accounting Research, 3(1), 112-122. https://doi.org/https://doi.org/10.1108/AJAR-06-2018-0007

Permatasari, D. M., \& Purposari, D. (2018). Pengaruh Tarif Pajak, Sunset Clause, dan Sosialisasi PMK Nomor 23 Tahun 2018 Terhadap Kemauan Untuk Patuh Wajib Pajak UMKM (Studi Kasus UMKM Banyuwangi). JIAP, 1(1), 1-21.

Sania, A. F., \& Yudianto, I. (2018). Analysis of Factors that Influence Taxpayers Compliance in Fulfilling their Taxation Obligations: Study of Small Medium Entrepreneur (SMEs) Taxpayers Based on eCommerce in the Bandung Area. Journal of Accounting Auditing and Business, 1(2), 17. https://doi.org/10.24198/jaab.v1i2.18270

Supriyono, A., Utami, I., \& Muktiyanto, A. (2021). Exploration of Tax Compliance Determination on Micro, Small and Medium Enterprise. Accounting Analysis Journal, 11(1), 33-52. https:// doi.org/10.33369/j.akuntansi.11.1.33-52

Taurina, I. P., Nudhana, \& Triana. (2017). Pengaruh Kualitas Pelayanan dan Sanksi Perpajakan Terhadap Kepatuhan Wajib Pajak. Accaunting Analysiss Journal, 3(2), 177-186.

Tucker, M., Jubb, C., \& Yap, C. . (2020). The theory of planned behaviour and student banking in Australia. International Journal of Bank Marketing, 38(1), 113-137. https://doi.org/https://doi.org/10.1108/IJBM-11-2018-0324

Yuliyanah, P. R., Noviany, D., \& Fanani, B. (2018). Pengaruh Omzet Penghasilan, Tarif Pajak, serta Self Assesment terhadap Kepatuhan Wajib Pajak Usaha Mikro, Kecil dan Menengah (UMKM) di Kota Tegal. Multiplier, 3(1), 11-29. 